\title{
STRATEGI PERITEL LOKAL DAERAH PASCA MASUKNYA PERITEL LOKAL NASIONAL DAN PERITEL ASING
}

\author{
Oleh:
}

Khusniyah Purwani, S.E., M.Si."

\begin{tabular}{l|l|l}
\hline & ABSTRAKSI &. \\
\hline & &
\end{tabular}

This article describes the conditions of local retailers after the penetration of national retailers and foreign retailers. A local retailers is one of retailers whose emergence originates from a local area. The form of their enterprises changes from the former conventional or traditional shops into local retailers which are managed according to modern standard with its "self service" concept after the penetration of national or foreign retailers. Several main factors that play important roles in the development of local retailers include capital resources, human resources, demographic characteristic, regulation, designs, merchandise and promotion. Think regionally and act locally strategy can be used to maintain consumers of local retailers.

Keyword: local retailers, national retailers, and foreign retailers

\section{A. PENDAhuluan}

Ritel mempunyai arti penjualan secara langsung. Usaha ini merupakan bagian paling akhir yang langsung memberikan pelayanan kepada konsumen dalam sebuah rantai distribusi. Pelayanan kepada konsumen secara langsung ini yang membedakan usaha ritel dengan jenis usaha lain dalam sebuah rantai distribusi. Usaha ritel dijalänkan dengan high volume, low gross margin, dan large-scale formats (Wileman, 1993). Jenis usaha ritel sangat bervariasi, tidak hanya dalam hal penyediaan produk barang berwujud (tangible product) saja, akañ tetapi termasuk pula penyediaan produk jasa (intangible product). Mulai dari usaha penjualan voucher yang hanya bermodal beberapa juta rupiah sampai pada jenis usaha pergudangan (warehouse) barang barang konsumsi (consumption product) dengan modal milyaran rupiah. Tulisan strategi peritel lokal daerah ini akan mengurai, memaparkan fenomena pasar ritel lokal di daerah-daerah yang pelan dan pasti harus bersaing menghadapi peritel besar nasional yang membuka gerai masuk ke daerah dan peritel asing berskala besar yang telah mendirikan outletnya lebih dulu.

Pasar secara umum adalah kegiatan penjual dan pembeli yang melayani transaksi jual-beli (www.id.wikipedia.org). Pengkategorian pasar tradisional dan pasar modem sebenamya bani muncul belakangan ini ketika mulai bermunculan pasar swalayan, supermarket, hypermarket dsb. Pasar tradisional merupakan

") Khusniyah Purwani, S.E., M.Si. adalah Staf Pengajar Program D3 FE UII. 
tempat bertemunya penjual dan pembeli, yang ditandai dengan adanya transaksi penjual pembeli secara langsung, bangunan biasanya terdiri dari kios-kios atau gerai, los dan dasaran terbuka yang dibuka oleh penjual maupun suatu pengelola pasar. Sedangkan Pasar modern adalah pasar yang penjual dan pembeli tidak bertransaksi secara langsung melainkan pembeli melihat label harga yang tercantum dalam barang (barcóde), berada dalam sebuah bangunan dan pelayanannya dilakukan secara mandiri (swalayan) atau dilayani oleh pramuniaga (www.id.wikipedia.org). Pasar ritel modern masih dibagi lagi ke dalam pasar ritel lokal dan pasar ritel asing. Pasar ritel lokal adalah usaha ritel di mana pemilik ritel atau peritel berasal dari lokal daerah dalam negeri Indonesia, dengan cakupan pasar konsumen meliputi nasional, propinsi atau kota tertentu saja. Pasar ritel lokal daerah menjadi salah satu bagian dari pasar ritel lokal dengan cakupan wilayah pasar konsumen pada suatu daerah tertentu, dan kemunculan pasar ritel ini dari daerah setempat. Format usaha peritel lokal juga mengalami perubahan semula berasal dari toko konvensional menjadi toko modern. Sedangkan pasar ritel asing adalah usaha ritel pendatang yang asalnya dari luar negeri, seperti Wal-Mart, Carrefour, atau Giant.

Belanja atau "shopping"sendiri dahulu menjadi kebiasaan bagi sebagian besar kaum perempuan, namun nampaknya saat ini sudah tidak menjadi dominasi kaum perempuan. Kehadiran pasar-pasar modern memang membuat belanja menjadi suatu wisata keluarga yang memberi pengalaman tersendiri. Seorang ayah tidak akan lagi malu berbelanja dan membeli sayuran di hypermarket. lbu-ibu yang bekerja masih dengan pakaian kerja juga terbiasa terlihat belanja daging atau ikan yang dikemas dengan kemasan hygienis, alumunium pack, dan tidak terkesan kotor atau berbau amis. Anak-anak juga akan merasa senang bisa memilih dan membeli barang-barang kesukaannya atau bermain dalam arena permainan anak sambil menunggu ibunya berbelanja. Pasar-pasar modem tersebut kini juga dikemas dalam tata ruang yang bagus, desain menarik, terang, lapang, dan ber-AC. Berbelanja tidak lagi disuguhi dengan suasana yang kotor, panas, bau, sumpek, dan becek: Pelayanan yang kurang mengenakkan seperti berhadapan dengan penjual yang tidak ramah jarang dijumpai di pasar-pasar modern. Singkatnya, kini belanja bukan hanya tugas ibu-ibu atau pembàntu rumah tangga. Belanja juga bukan lagi menjadi kegiatan yang membosankan tetapi bisa menjadi wisata keluarga.

\section{B. KATEGORI JENIS RITEL MODERN}

Dalam peta industri ritel modern di Indonesia, terdapat beberapa format ritel yaitu:

Minimarket didefinisikan sebagai toko yang menjual eceran barang konsumsi, terutama produk makanan dan produk rumah tangga. Luas lantai bangunan usaha penjualan adalah kurang dari $400 \mathrm{~m} 2$. Berlokasi di setiap sistem jaringan jalan, jalan lokal, daerah perumahan, dan pusat kota.

Department store adalah toko yang menjual secara eceran barang konsumsi, sandang, dan pangan dengan penataan barang berdasarkan jenis kelamin atau usia konsumen. Mempunyai luas lantai bangunan usaha diatas 
Khusniyah Purwani: Strategi Peritel Lokal Daerah Pasca Masuknya Peritel Lokal Nasional...

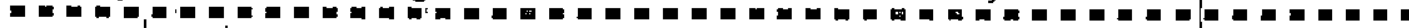

$400 \mathrm{~m} 2$. Berlokasi di daerah padat aktivitas ekonomi masyarakat dan mempunyai areal parkir minimal $100 \mathrm{~m} 2$.

Supermarket mempunyai karakteristik toko yang menjual eceran barang konsumsi, terutama produk makanan dan produk rumah tangga lainnya. Luas lantai bangunan usaha penjualan berkisar $400-5000 \mathrm{~m} 2$. Berlokasi di pusat aktivitas ekonomi masyarakat dan jalan lokal serta mempunyai areal parkir minimal $100 \mathrm{~m} 2$.

Hypermarket adalah toko yang menjual barang konsumsi, produk makanan dan rumah tangga lainnya. Pelayanan berorientasi mandiri dan mempunyai areal parkir minimal $100 \mathrm{~m} 2$. Mempunyai luas bangunan lokasi usaha di atas $5000 \mathrm{~m} 2$ serta berlokasi di pusat perkotaan dan padat aktivitas ekonomi masyarakat.

Sementara itu, grosir adalah toko yang mempunyai luas bangunan di atas $5000 \mathrm{~m} 2$. Menjual barang konsumsi secara grosir serta berlokasi pada akses sistem jaringan jalan arteri atau jalan kolektor (Berman, 1995). Di Indonesia dalam menjalankan usaha ritel modern, sudah terdapat aturan yang mengatur tentang zona pendirian (zonasi). Hal ini dimaksudkan agar tidak terjadi persaingan usaha tidak sehat yang dapat merugikan pelaku usaha lain.

Dengan segala macam variasi yang ditawarkan, tentu saja dengan mudah pasar-pasar modern akan menarik perhatian masyarakat. Pangsa pasar yang selama ini dikuasai pasar tradisional dan peritel konvensional perlahan tapi pasti mulai beralih. Peritel besar nasional masuk ke daerah daerah melalui beberapa cara. Salah satunya dengan cara membuka cabang baru pada suatu kota atau melalui sistem franchise (waralaba), mengakuisisi dengan membeli saham kepemilikan peritel yang telah lebih dulu ada. Peritel besar nasional membuka gerai atau outletnya tidak hanya di pusat kota bahkan membukanya sampai tingkat kecamatan. Besar kemungkinan kondisi ini akan menggeser pelanggan toko ritel lokal daerah atau toko konvensional menjadi pelanggan toko ritel modern nasional.

Didukung dengän pola manajemen, infrastruktur, dan sistem informasi canggih, bukan tidak mungkin pasar-pasar modem ini akan menggantikan fungsi pasar tradisional, termasuk menggeser peran peritel lokal daerah dalam beberapa waktu mendatang. Kebiasaan berbelanja (habit consumption) yang dahulunya banyak dijumpai di pasar tradisional; warung-warung, dan toko-toko konvensional, nampak sudah bergeser mengarah ke pusat-pusat perbelanjaan, mallmall, mega-center, trade center, atau ke pasar ritel modern independent. Pasar tradisional dan pasar ritel lokal daerah tidak lagi bisa menjadi raja. Berbagai faktor yang menyebabkan pergeseran pola belanja masyarakat diantaranya seperti adanya: perubahan dinamika masyarakat (muncul budaya instan, tersedianya beragam makanan cepat saji, menjamurnya restoran yang menyediakan segala makanan minuman yang sangat bervariasi), perkembangan teknologi informasi, serta adanya pergeseran dan pengaruh status kelas sosial dalam masyarakat. Kondisi ini menjadikan masyarakat cenderung lebih memilih berbelanja di tempat yang nyaman, bersih; ber-AC, dengan penyediaan barang yang lengkap, harga bersaing serta menyediakan berbagaifasilitas pendukung laị yang menjadikan pasar ritel lokal daerah, toko konvensional dan pasar tradisional semakin banyak ditinggalkan oleh pelanggannya. 
Konsep yang ditawarkan pasar ritel lokal konveṇsional atau tradisional berupa "melayani pembeli" nampaknya hanya akan terlihat di pasar-pasar tradisional yang jumlahnya semakin lama semakin menyusut. Sedangkan pasar ritel modern dijalankan dengan konsep "self service atau swalayan" yang saat inị sudah menjadi trend digemari oleh calon konsumen. Perpindahan habit daii semula konsumen pasar konvensional pasar tradisional menjadi konsumen pasar modern bukan mustahil akan terjadi. Sehingga menyebabkan peritel lokal beralih konsep usaha menggunakan konsep self service atau swalayan, di mana konsumen calon pembeli bebas melayani dirinya sendiri dalam bertransaksi.

\section{Pasar Modern: Pasar Peritel Nasional dan Peritel Asing}

Fenomena pasar tradisional nampaknya bertolak belakang dengan perkembangan pasar modern. Dewasa ini pasar ritel modern tumbuh menjamur bagaikan pertumbuhan bank pada sepuluh tahun yang lalu. Pasar ritel modern tumbuh dengan konsep "swalayan". Swalayan dapat diartikan "melayani sendiri", yaitu konsumen yang berbeläja akan melayani dirinya sendiri. Konsep yang ditawarkan berkebalikan dengan model pasar ritel tradisional yang ada, di mana konsumen pembeli akan dilayani oleh penjual atau pramuniaga dan harus rela menunggu giliran untuk dilayani. Perbedaan ini yang dirasakan oleh peritel dan bahwa konsep swalayan lebih tepat untuk saat ini, lebih berorientasi kepada konsumen dan memberikan nuansa kebebasan daripada konsep melayani dalam pasar ritel tradisional. Kondisi ini diperkuat dengan dukungan pemerintah dalam bentuk regulasi pemerintah.

Bentuk regulasi dari pemerintah berupa kemudahan untuk membuka atau mendirikan pasar modem, yang akhimya menjadi peluang bagi masuknya peritel besar nasional atau peritel lokal skala nasional ke daerah-daerah. Di sisi lain menjadi bumerang bagi perkembangan pasar tradisional. Regulasi ini tertuang dalam Keppres no 96/1998 tentang Bidang Usaha Yang Tertutup dan Bidang Usaha Yảng Terbuka dengan Persyaratan Tertentu Bagi Penanaman Modal. Keberadaan Keppres ini telah mengundang masuk retailer asing untukmembuka usahanya di Indonesia. Sampai pertengahan tahun 2003 (Kapanlagi.com, 2003) jaringan multinasional yang masuk ke Indonesia sudah mencapai 15 gerai. Kemudahan untuk membangun pusat perbelanjaan modern skala besar ini menjanjikan banyak pemasukan bagi pendapatan anggaran daerah. Mulai dari izin mendirikan bangunan, PBB (pajak, bumi dan bangunan), pajak pendapatan restoran, pajak toko dan gerai, pajak reklame indoor, pajak outdoor, pajak parkir dari pengelola, pajak penerangan jalan, retribusi parkir, nilai jual tenaga listrik, dan lain-lain (www.institute for research and empowerment, 26 Oktober 2008).

Bisnis.com (Rabu 15 Juni) menyebutkan bahwa jumlah hypermarket di tahun 2003 baru berjumlah 43 unit saja. Angka ini terus saja naik menjadi 68 unit di tahun 2004 hingga tahun 2005 sudah meningkat menjadi 83 unit hypermarket. Menurut AC Nielsen dalam bisnis.com pertumbuhan mal dan hypermarket yang masuk ke kampung-kampung di negeri ini setiap tahunnya mendapai 31,4 persen (lihat Tabel). 
Khusniyah Purwani: Strategi Peritel Lokal Daerah Pasca Masuknya Peritel Lokal Nasional...

Tabel Pertumbuhan Ritel Modern Tahun 2003 - 2005 Jumlah Ritel Modern di Indonesia

\begin{tabular}{|l|c|c|c|}
\hline \multicolumn{4}{|c|}{ Jumlah Ritel Modern di Indonesia } \\
\hline Jenis Ritel & 2003 & 2004 & 2005 \\
\hline Convenience Store & 102 & 154 & 131 \\
\hline Supermarket & 896 & 958 & 961 \\
\hline Mini Market & 4.038 & 5.604 & 6.272 \\
\hline Hypermarket & 43 & 68 & 83 \\
\hline Warehouse/Grosir & 24 & 22 & 23 \\
\hline Jumlah & 5.103 & 6.806 & 7.470 \\
\hline Peningkatan (\%) dari tahun 2003 & & $33,3 \%$ & $146 \%$ \\
\hline $\begin{array}{l}\text { Peningkatan (\%) dari 2001 } \\
\text { (n=3865) }\end{array}$ & $132 \%$ & $176 \%$ & $193 \%$ \\
\hline Sumber; AC Nielsen (sampai dg tahun 2005) \\
Jumlah Ritel Modern Indonesia .
\end{tabular}

Jumlah Ritel Modern Indonesia

\section{0}

Unit 4000 2000
0 - $\frac{A}{1}$


Tahun $2003-2005$.

5.

Sumber; AC Nielsen (sampai dg tahun 2005)

Kehadiran dua peritel hypermarket besar, yakni Carrefour (Perancis) dan Giant (Malaysia) menguasai 29,2\% pasar ritel Indonesia. Hingga tahun 2002, 2031 gerai pasar modern nasional membukukan omzet 33 triliun, sedangkan hypermarket asing dengan 15 outlet sudah mampu membukukan 10,88 triliun. Suatu perbandingan yang mencolok, peritel asing dengan beberapa outlet sudah dapat membukukan omzet sepertiga dari seluruh omzet gerai pasar modern nasional. Seperti yang dilakukan oleh PT.Carrefour Indonesia yaitu dengan menambah lima toko dan Hypermarket (Matahari Putra Prima Tbk) membuka enam gerai baru. Target peritel asing di Indonesia setiap tahunnya adalah menambah gerai baru hypermarket $10-12$ toko per tahun. Contohnya pada tahun 2006; Carrefour dan Hypermarket masing-masing mermbuka 10 toko, 
termasuk satu diantaranya yang dibangun dalam waktu yang hampir bersamaan di Yogyakarta.

Kondisi ini berkebalikan dengan perkembangan pasar tradisional/ konvensional yang pertumbuhannya mengalami penurunan. Meskipun jumlah pasar tradisionai/ konvensional ribuan, namun pasar ini nyariș tanpa perkembangan. Ambil contoh saja kota Jawa Tengah, seperti ditulis dalam (Suara Merdeka.com, 26 Nopember 2007) tahun 2001 terdapat 1445 pasar tradisional, setahun kemudian meningkat menjadi 1512 atau naik $4,6 \%$, namun setelah itu terjadi penurunan jumlah pasar tradisional kira kira 1,5\%, penurunan terbesar terjadi pada tahun 2005 sebesar $3,5 \%$.

\section{Pasar Tradisional: Pasar Peritel Lokal Daerah}

Melihat data perkembangan peritel besar nasional dan intemasional pada akhir tahun 2007 sampai dengan sekarang, menjadikan peritel lokal daerah bisa sedikit bernapas lega sebentar. Bisnis Indonesia (30 November 2008) menyebutkan bahwa pembukaan gerai hypermarket melambat hingga $30 \%$ sampai dengan November 2007. Kondisi ini dipicu banyaknya kontra yang muncul setiapkali peritel modern membuka toko berskala besar tersebut. Sebut saja salah satu kabupaten di wilayah Yogyakarta, Kabupaten Bantul, yang pada tahun 2008 ini telah menghentikan ijin pendirian pasar ritel modem berskala nasional (supermarket), sehingga bagi yang ingin mendirikan harus bersabar dahulu. Kebijakan Bupati Bantul ini dimaksudkan untuk melindungi pasar tradisional dan usaha ritel kecil milik rakyat.

Berkaca dari apa yang dilakukan Kabupaten Bantul, nampaknya kotakota lain perlu membenchmark melakukan hal yang sama guna melindungi pasar tradisional dan peritel lokal daerah. Langkah ini secara tidak langsung melindungi petani lokal, pedagang-pedagang kecil, dan rakyat kecil yang asli anak bangsa ini. Di sisi lain dukungan dari pemerintah nampak sudah ada dengan keluarnya peraturan yang isinya untuk melindungi pasar tradisional. Melalui Peraturan Presiden (Perpres) No.112/2007 tentang. Penataan dan Pembinaan Pasar Tradisional, Pusat Perbelanjaan dan Toko Modern, yang dikeluarkan pada tanggal 27 Desember 2007, pasar tradisional dan pasar ritel lokal daerah bisa sedikit berlega bahwa ada upaya pemeintah terhadap kondisi pasar tradisional dan pasar ritel lokal daerah ke arah perbaikan.

Pertumbuhan omzet ritel lokal diperkirakan akan meningkat sebesar $17 \%$ pada tahun ini, sedangkan pada 2008 diprediksi start dengan 15\%. Seperti juga daur hidup produk, ritel modern nasional dan asing juga mengalami daur hidup, jika tidak digenjot dengan stimuli yang berbeda dampaknya akan stagnan, konsumen bosan atau bahkan mengalami kemunduran. Peluang ini menjadi celah atau relung bagi peritel kecil atau peritel lokal daerah untuk menangkapnya sebagai lahan yang belum terlayani. Terlebih dengan kondisi selama ini di mana peritel lokal daerah berposisi sebagai follower peritel besar nasional atau peritel asing, yang tidak bisa selalu mengikuti perkembangan peritel besar nasional. Sebelum peritel lokal menemui kondisi kejenuhan seperti peritel besar nasional, perlu dicermati bersama kondisi peritel lokal daerah sebelum menjadi bumerang bagi peritel lokal daerah. 


\section{Kondisi Peritel Lokal Daerah}

Peritel lokal daerah adalah salah satu jenis peritel yang kemunculannya berasal dari daerah setempat. Format usaha mereka berubah dari semula toko konvensional, atau bagian dari pasar tradisional menjadi ritel modern dengan konsep "self service". Perubahan format usaha dilakukan untuk menyesuaikan mengikuti trend keinginan konsumen. Langkah ini tidak begitu saja dapat dilakukan, karena banyak faktor yang harus disesuaikan mengikuti perubahan format usaha tersebut (Sinha, 2004). Beberapa faktor utama|kondisi peritel lokal daerah yang perlu dicermati adalah sebagai berikut:

\section{Sumber Daya Modal Peritel Lokal Daerah}

Terbatasnya sumber daya atau resource yang dimiliki peritel lokal daerah menyebabkan gerak langkah peritel lokal daerah tidak secepat gerak peritel besar nasional. Hal ini'menyebabkan gerak peritel lokal daerah lamban dibandingkan dengan peritel besar nasional. Modal yang dimiliki peritel lokal biasanya berasal dari modal sendiri, akumulasi laba, hasil perkembangan usaha sejak awal, atau kucuran kredit dari lembaga keuangan. Sumber daya modal lebih diprioritaskan untuk menambah jumlah item barang atau menambah variasi merchandise. Sementara sumber daya modal pada peritel besar nasional sudah mapan. Peritel besar nasional atau asing mendapatkan pemasukan dari listing fee per item barang, display fee, dan discount periode fee dari pemasok barang dagangan (merchandise). Sehingga dari daftar barang dagangan (merchandise) saja peritel besar nasional sudah mendapatkan pemasukan, sedangkan peritel lokal daerah tidak mendapatkan, suatu hal yang amat mencolok.

\section{Sumber Daya Manusia Peritel Lokal Daerah}

Kualitas sumber daya manusia (human resource) atau karyawan yang dimiliki peritel lokal secara rata rata belum bisa menyamai kualitas karyawan peritel besar nasional atau asing. Manajemen sumber daya manusia pada peritel lokal masih kalah fleksibel dibandingkan dengan manajemen sumber daya manusia pada peritel asing. Masih sering ditemui konsumen mengeluh karena pelayanan karyawan toko ritel lokal daerah yang tidak ramah dan tidak profesional kepada konsumen. Kemampuan product knowledge yang dimiliki karyawan ritel lokal masih rendah, tidak menunjukkan emphaty kepada konsumen dan tingkat responsiveness karyawan yang masih rendah.

\section{Regulasi}

Regulasi pemerintah mengenai pasar ritel tradisional, pusat perbelanjaan dạn pasar modern nampaknya belum bisa memberikan perlindungan secara penuh terhadap pasar tradisional dan peritel lokal daerah apalag melindunginya dari gurita peritel asing. Enam pokok masalah dalam Perpres itu meliputi definisi, zonasi, kemitraan; perizinan, syarat perdagangan (trading term), kelembagaan pengawas, dan sanksi. Soal zonasi atau tata letak pasar tradisjonal dan pasar modern (hypermart), menurut Perpres, disusun oleh Pemerintah Daerah (Pemda), padahal masaiah tata letak peritel asing inilah yang sering kali menimbulkan masalah dengan masyarakat sekitar. 
Kedatangan peritel asing, peritel besar nasional pada suatu kota propinsi atau kota kecil telah menjadi lahan pemasukan pendapatan daerah yang cukup besar, sementara untuk berdirinya sebuah peritel lokal daerah yang berskala kecil belum bisa menandinginya. Cukup variatif jenis dan besar pemasukan daerah yang berasal dari masuk atau datangnya peritel besar nasional ini, sehingga kran untuk pembukaan gerai peritel besar nasional terbuka lebar. Keberadaan pasar modem menjadi daya tarik tersendiri bagi sebuah kota dalam menarik konsumen luar kota untuk datang ke kota dengan tujuan untuk berbelanja. Pembangunan pusat-pusat perbelanjaan di kota Yogyakarta, jika tidak dibangun dan dibuka di Yogyakarta, kemungkinan kesempatan ini akan diambil oleh daerah sekitar Yogyakarta seperti Purworejo, Surakarta dan lain sebagainya. Dikhawatirkan akan menjadikan Yogyakarta menjadi tertinggal dan ditinggalkan oleh para wisatawan domestik. Pertimbangan atau wacana ini yang lebih menguak daripada nuansa keinginan untuk lebih melindungi peritel lokal daerah.

\section{Karakteristik Demografi Konsumen}

Zeithaml (1985) dalam Carpenter (2006) dalam studi lapangan menguji pengaruh lima variabel demografi (gender, status wanita pekerja, usia, pendapatan, dan status perkawinan) terhadap variabel berbelanja ke supermarket (waktu berbelanja, jumlah supermarket yang dikunjungi dalam setiap minggunya, jumlah uang yang dialokasikan untuk berbelanja). Studi ini menemukan adanya pergeseran dalam karakteristik demografi konsumen supermarket dengan konsumen pasar tradisional. Studi ini menekankan pula bahwa perubahan jumlah anggota dalam keluarga (meningkatnya wanita yang bekeja, laki-laki berbelanja, single, bercerai atau hidup menjanda/ menduda) akan mengarah pada perubahan dalam pemilihan tempat berbelanja. Artinya karakteristik demografi konsumen berpengaruh terhadap keputusan format ritel yang dipilih bagi peritel lokal.

\section{Desain (Design)}

Desain gerai atau desain outlet peritel lokal daerah dibandingkan dengan desain gerai peritel besar nasional dan gerai peritel asing secara umum kalah menarik. Persuasi dan stimuli yang terpancar dari desain gerai akan berpengaruh terhadap daya tarik konsumen ritel. Sebelum konsumen memutuskan untuk membeli pada suatu peritel tertentu maka yang dilihat pertama adalah rangsangan desain gerai (Wheatley, 1986) atau outletnya. Setelah konsumen masuk ke gerai atau outlet barulah konsumen akan melihat rangsangan atau stimuli berupa display barang dagangan. Tertariknya seorang konsumen terhadap desain gerai akan berpengaruh terhadap keputusan pilihan toko ritel (Baker, 2002). Hubungan antara lingkungan toko, desain toko, dan atmosfir toko menjadi fokus objek dalam menciptakan proses yang kreatif di dalam toko, visual merchandising, dan branding (Kent, 2007). Sehingga daya tarik konsumen melalui desain eksterior dan interior toko (visual merchandising) menjadi faktor penting bagi peritel lokal dalam mengemas tampilan peritel. 
Khusniyah Purwani: Strategi Peritel Lokal Daerah Pasca Masuknya Peritel Lokal Nasional...

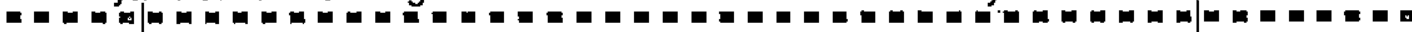

\section{Barang dagangan (Merchandise)}

Kegiatan pengadaan barang dagangan (merchandise) merupakan kegiatan operasional ritel yang uțama (Erdem.et.al, 1999). Sebesar 60\% dari seluruh modal dianggarkan untuk pengadaan barang dagangan, sedangkan sisanya baru dipenuntukkan bagi kebutuhan sarana prasarana yang lain. Barang dagangan yang ditawarkan oleh peritel besar bisa mencapai puluhan ribu item barang, sementara pada peritel lokal baru mencapai ribuan item barang. Peritel lokal daerah lebih menggunakan kemampuan budgetnya untuk pengadaan barang seoptimalnya, sementara peritel besar nasional sudah melampdui hal itu masih ditambah lagi banyaknya produk luar yang menghendaki barangnya ikut di tawarkan di outlet. Barang dari pemasok eksternal yang menghendaki ikut dipajang dapat menambah daftar item barang sekaligus dapat memberikan pemasukan (listing fee, display fee, dan discount periode fee) bagi peritel besar nasional, yang tidak diperoleh dan jarang dijumpai pada peritel lokal daerah. Peritel lokal daerah masih sering menggunakan sistem konsihyasi dan baru beberapa saja yang menerapkan listing fee, maupun display fee. Dengan kondisi ini peritel lokal tidak mendapatkan pemasukan lain selain dari laba atas barang konsinyasi.

\section{Promosi}

Strategi promosi yang dilakukan oleh peritel besar nasional maupun peritel asing sudah tidak diragukan lagi. Promosi yang telah terprogram, terstruktur, desain promosi yang terpusat dan program promosi yang didesain oleh local branch. Desain promosi, style promosi, sumber daya manusia dan biaya promosi merupakan faktor-faktor yang membedakan peritel lokal daerah dengan peritel lokal nasional. Bagaimanapun juga pentel lokal daerah perlu belajar banyak dari peritel besar nasional atau peritel asing, dengan tidak meninggalkan unsur kedaerahan yang ada. Melihat kondisi yang ada perlu dirumuskan strategi yang dapat mengangkat peritel lokal dalam peta persaingan peritel, baik dengan peritel lokal nasional maupun dengan peritel asing.

\section{Strategy: Think Regional Act Locally}

Beberapa kelemahan yang dapat dicermati dari peritél lokal daerah, bukan berarti peritel lokal tidak memiliki kekuatan. Potensi lokal yang dimiliki peritel lokal dapat dijadikan modal keunggulan kompetitif untuk menggaet konsumen. Salah satunya adalah service. Pemberian service atau pelayanan yang memuaskan kepada setiap pelanggan dapat menjadi alat untuk menggapai konsumen. Penerapan strategi berpikir regional dan bertindak lokal secara arif (think regional and act locally) dapat digunakan untuk mendukung upaya mempertahankan pelanggan. Hạl ini dapat dilakukan melalui beberapa hal yaitu:

\section{Kerjasama (Partnership)}

Berpartner dengan distributor dan konsumen mienjadi salah satu andalan dalam strategi untuk mempertahankan dan memenangkan persaingan ritel. Partnership dengan distributor dapat dilakukan dalam upaya mengembangkan usaha ritel melalui promosi dan komunikasi sehingga tidak hanya menjadi tanggungjawab peritel lokal saja. Partnership dengan konsumen dilakukan 
melalui networking komunikasi untuk menginformasikan produk baru, program promosi atau harga produk baru.

\section{Standar global (Global standard)}

Peritel lokal harus menetapkan sebuah standar yang global dalam menjalankan usahanya. Implementasi strategi bauran pemasaran (produk, harga, promosi dan distribusi) harus berorientasi kepada standar yang global sehingga akan mudah diterima oleh siapapun segmen konsumennya. Misalnya dalam hal pelayanan, tentunya pelayanan yang diberikan mengacu kepada customer oriented (berorientasi kepada konsumen), demikian pula dalam kasus penyelesaian complain dari konsumen, dilakukan dengan tetap berorientasi kepada kepuasan konsumen.

\section{Perspektif Regional (Regional Perspectif)}

Seperti juga merek, maka posisi peritel lokal tetap harus mempertahankan perspektif regional. Maksudnya, walaupun banyak peritel asing (dari Perancis, Amerika, atau Malaysia) masuk ke Indonesia, semestinya peritel lokal tetap mempertahankan perspektif regional Indonesia. Peritel Indonesia tetap fokus kepada regional dan strategi regional dalam hal segmentasi, targeting dan positioning.

\section{Bertindak Lokal (Act Local)}

Hal berikutnya yang penting bagi peritel lokal adalah bertindak lokal maksudnya menjadi local champion. Peritel lokal dengan fokus regional harus mengerti situasi pasar lokal dan memiliki sensitivitas tinggi terhadap budaya lokal. Act Loca/diartikan melakukan penyesuaian dalam strategi 4p yaitu product, price, place dan promotion yang mengerti dan memahami kebutuhan dan keinginan lokal (Mix, 2005). Act local dapat dilakukan dengan promosi lokal, promosi dengan bahasa lokal, menjalin komunikasi yang terpelihara dengan konsumen lokal, dan membangun networking dengan distributor lokal setempat. Implementasinya dapat dilakukan diantaranya dengan:

\subsection{Produk Lokal yang Praktis}

Pahami bahwa konsumen ritel adalah orang yang menyukai kepraktisan, sehingga strategi menawarkan produk yang praktis tepat digunakan. Produk dengan kemasan praktis, cara konsumsi praktis, penyediaan produk praktis menjadi pilihan tepat. Segala bentuk tawaran produk yang praktis akan menjadi sasaran pilihan konsumen. Banyak variasi produk lokal daerah yang saat ini mulai dan bisa dikemas dengan konsep praktis yang bisa ditawarkan dan masuk jajaran listed product swalayan.

\subsection{Produk lokal daerah (Local product)}

Sebagian besar konsumen ritel lokal daerah adalah konsumen yang berpendidikan. Segmen ini menjadikan peritel lokal harus jeli untuk memanfaatkannya dalam strategi berpromosi. Edukasi konsumen menjadi konsumen yang mencintai produk lokal bukan hal yang mustahil akan 
Khusniyah Purwani: Strategi Peritel Lokal Daerah Pasca Masuknya Peritel Lokal Nasional...

berhasil dengan gemilang. Bagaimanapun juga konsumen ritel modern adalah warga regional, pribumi bangsa Indonesia, yang lahir, besar dan hidup di Indonesia. Kecintaan konsumen kepada Indonesia sedikitbanyak dapat dijadikan senjata untuk menggugah rasa empatinya terhadap produk lokal. Kategorisasi produk berdasar asal daerah penghasil produk dapat menjadi strategi untuk mengangkat produk lokal daerah sekaligus menarik perhatian konsumen untuk lebih mencintai produk lokal daerah.

\subsection{Merek Lokal Daerah (Local Brand)}

Merek (brand) merupakan magnet untuk menarik konsumen, mempertahankan dan memelihara konsumen ritel (Uusitalo, 2001). Merek lokal daerah perlu digunakan untuk mengangkat nama daerah penghasif produk, memberikan informasi yang akurat bahwa merek daerah tidak kalah bersaing dengan merek asing. Sebagai contoh: Beras Organik Purbalingga, (beras organik lokal), Mangga Hanum Manis Indramayu (buahbuahan lokal), Teh Hijau Sukabumi ( produk teh asli kebun Sukabumi), Sale Bali (sale asal pulau Bali). Merek-merek produk dengan nama daerah tersebut akan meningkatkan cognitif konsumen bahwa daerah-daerah di belahan pulau Indonesia ini ternyata memiliki keunggulan yang beraneka ragam. Nama merek lokal daerah mudah diingat oleh konsumen Indonesia. Local brand ini dapat menjadi satu competitive advantage bagi peritel lokal daerah.

\subsection{Image Peritel (Corporate Brand Image)}

Image perusahaan atau citra peritel mempunyai pengaruh terhadap kepuasan konsumen dan loyalitas peritel (Martenson, 2007). Image peritel merupakan kombinasi pengaruh dari bagaimana melihat peritel sebagai merek, merek pabrik, dan merek toko bagi konsumen. Image peritel sebagai sebuah merek menjadi variabel penting dalam kepuasan konsumen. Konsumen merasa puas manakala peritel terlihat rapi dan menyenangkan, demikian pula ketika konsumen merasa bahwa peritel dapat memahami dan mengetahui kebutuhannya.

\subsection{Promosi lokal (Local Promotion)}

Promosi lokai dapat dilakukan melalui berbagai macam cara, promosi . dengan bahasa lokal setempat, media yang digunakan adalah media promosi lokal setempat, endorser lokal, iklan lokal, media cetak lokal, media audio visual lokal, dan lain sebagainya. Alat dan media promosi lokal tidak kalah menarik untuk menarik konsumen bahkan menjadi lebih fokus untuk segmen konsumen lokal.

\section{Kesimpulan}

Berbagai uraian di atas dapat disimpulkan bahwa pemerintah telah mengeluarkan regulasi untuk menata pengelolaan pasar, baik pasar modern maupun pasar tradisional. Regulasi itu tertuang dalam Peraturan Presiden (Perpress) No.112/2007 tentang Penataan dan Pembinaan Pasar Tradisional, 
Pusat Perbelanjaan dan Toko Modern. Regulasi itu akan memudahkan gerak peritel lokal daerah untuk mengembangkan usahanya apabila didukung. implementasi kebijakan yang konsisten dari pemerintah dan pelaku usaha ritel. Pembebanan pajak masuk yang tinggi kepada produk impor, membatasi atau melarang promosi produk impor juga akan memberikan dampak yang cukup signifikan terhadap kemandirian produk lokal daerah. Pada akhimya diharapkan produk daerah akan dapat menggeser produk impor.

Kehadiran pasar modem memang telah memberikan dampak kepada pasar ritel lokal daerah. Sehingga diperlukan langkah-langkah preventif untuk menjaga kelangsungan pasar ritel lokal daerah termasuk kelangsungan hidup pedagang kecil lokal, toko-toko konvensional maupun pasar tradisional. Salah satu strategi yang dapat digunakan untuk menjaga agar pasar ritel lokal daerah dapat hidup dan berkembang adalah melakukan think regional act locally, melalui partnership, global standard, regional perspectiv dan act locally dengan penawaran produk lokal yang praktis, produk lokal daerah, merek lokal daerah, image peritel lokal dan promosi lokal. Strategi ini akan berhasil baik dengan dukungan dari pemerintah dan komitmen pelaku ritel yang tinggi.

\section{DAFTAR PUSTAKA}

Baker, Julie, .et.al., (2002)," The influence of multiple store environment cues on perceived merchandise value and patronage intentions", Joumal of Marketing, Vol.66, Iss. 2; pg. 120-122

- Berman, Barry \& Evans, Joel R., (1995), "Retail Management; A Strategic Approach", Sixth edition, Prentice Hall, Englewood Cliffs, New Jersey.

Bisnis Indonesia, 30 November 2008

Carpenter, Jason dan Mooré., (2006),"Consumer demographic, store attributes, and retail format choice in the US grocery market", International Journal of Retail \& Distribution Management, Vol 34, No.6, p.434452

Degeratu, Alexandru M.,(2000)," Consumer choice behavior in on line and traditional supermarket :The effects of brand name, price, and other search attributes", International Journal of Research in Marketing, Vol 17.p. $55-78$.

Direktur Jenderal Perdagangan Dalam Negeri, Pengaturan, Pengelolaan, dan Pengembangan Citra Pasar Tradisional di Wilayah Perkotaan dan Desa, 3 Juli 2007

Erdem, Orhan, et.al. (1999),"Consumer values and the importance of store attributes", International Journal of Retail \& Distribution Management; Vol 27, No. 4. p.137-144 
Khusniyah Purwani: Strategi Peritel Lokal Daerah Pasca Masuknya Peritel Lokal Nasional...

Kent, Tony., (2007)," Creative space: design and retail environment", International Journal of Retail \& Distribution Management, Vol.35, No.9., p.734-745

'Knox, Simon dan Denison., (2000)," Store loyalty: its impact on retail avenue. An empirical study of purchasing behaviour in the UK", Journal of Retailing and Consumer Services, Vol 7, p.33 - 45

Marketing, No.03/ VI/Maret/ 2006

Martenson, Rita., (2007), " Corporate brand image, satisfaction and store loyalty", International Journal of Retail \& Distribution Management, Vol.35, No.7, p.544-555

Mix, Marketing, Selling, PR, Advertising, Promotion \& Media, No.08/I!/ 13 Agustus 2005

Radar Jember, 22 November 2008

Sinha,Piyush Kumar dan Banerjee., (2004),"Store choice behaviour in an evolving market", International Journal of Retail \& Distribution Management, Vol. 32, No.10., p.482-494

SWA, Edisi Desember 2004

Uusitalo, Outi., (2001), "Consumer perceptions od grocery retail formats and brands", International Journal of Retail \& Distribution Management, Vol 29, No. 5. p.214-225

Warta Ekonomi, Pasar Tradisional di bawah bayang bayang "raksasa" Carrefour; 18 Desember 2008

Wheatley dan Chiu.,(1986),"The effects od price, store image, and product and respondent characteristics on perceptions of quality", Journal of Marketing Research, May, vol 14.p.181.

Wileman, Andrew., (1993)," Destination Retailing", International Joumal of Retail \& Distribution Management, Vol 21, No.1, p.3-9

www.bisnis.com, Rabu 15 Juni 2007

www.id.wikipedia.org

www.institute for research and empowerment, 26 Oktober 2008

wwiv.kapanlagi.com, 2003

www.kompas.com, 23 Maret 2007

www.prakarsa- rakyat.org, 7 Desember 2007 
www.scarborough.com.,(2005), "A Comparisons of Wal-Mart and Target Shoppers", Scarborough Multi - Market Study, December www.suara merdeka.com, Pasar tradisional vs Pasar Modern, 26 Nopember 2007 